が少く，塗被面の惡い紙は讀みの相異が大きい，これ は大きな問題があり以下の項浪於て檢討する.少くと も同樣材料汇對して四つの連續した紙を試驗して全部 の紙を見積る、試驗した紙の印刷澲する評價と，印 刷を行うには多くの試驗經驗と印刷後の觀察を必要と するが，數カ月の經驗から 0.15 と 0.28 の間の染及 出しを示寸紙が一般化最もよい結果を與えている，其 の他の值を示す紙對してはチョーキングやオフセッ ティングを防ぐベきインキを巧みに使用せねね゙ならな い高い讀及或は高い, 吸收值を示寺紙飞は少々硬い, ボデイワニスをもつたインキか或は“表面に止る”傾 向をもった合成樹脂を含んだインキを必要とし，一方 低い吸收率の紙には高、色調をもつた浸透のよい軟い インキを必要とする。染みの方法の特色として非常化 興味や價值のあることは，その一つとして污れのある 塗被紙を發見出來ることで心る。染及の或るすのは明

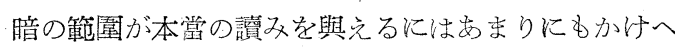
だたつているので良い讀み学其えないが，染みが作ら れて後, 認められる明腤の圖柄は惡いインキの浸透し
た範園と正狀のインキの浸透した範園と混同して指示 される. 或特殊な場合に於ては此の方法により紙全體 に斑點をつけ，此の上に印刷したものははなはだしく 班色となる。斯くして染みの方法は惡い紙を發塄しそ れを除去する助けとなる。ミルチンテッドペーパーに 於ては色の效果を消却するべき色フィルターを使用す る事が變つている。例党ばアイボリー, コーテッドペ 一パーを試驗する時は E. G. スペクトロホトメーター を以て分析した見本を使用する。アイボリー，コーテ ッドペーパーは白い紙と比較すると 600 と 700 ミり ミクロンの間の波長の所が凹んだ反射率曲線をもつて

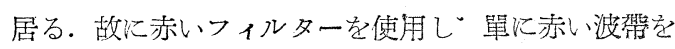
考える事仙よつて正狀の讀及を得る事が出來る。

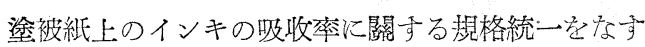
ための現在の試みは原始的ではあるが斯くの如き方法 が慜紙業者，インキ業者同樣な紙消費者の利易のため に非常に良い考光をもたらすところの充分は批制学を 活動し易くすると云う確信を以て行われている。

\title{
Phenomenon of Bronze in Surface Coatings
}

\author{
G. L. Buc, R. H. Kienle, L. A. Meloheimer, and E. I. Stearns
}

Ind. and Eng. Chem. vol. 39. No. 2, 147-154 (1947)

東涛インキ製造㧣式會社吉 本隆明

印刷インクや鋈料の皮膜などでしばしば觀察される ブロンブ現象沈は（i）單一な構造をもつた輚面か ら光が選擇的に反射されるため格じる“interface broze” と (ii). 極めて近接した構造體から反射された 光が選擇的に干涉し全うために生じる“interference bronz”の二型が崩る“interface bronze”の場会は視府を色々に變光るとブ ロンズの色相もいろいろに變るけれど “interface bronge”ではブロンズの色 相は大體一定に保たれているから差別寸 ることが出來る。

ブロンズを測定するには暴つた多くの 波長について試料の相對的な反射率を決 定すればよい外れぞ，普通の分光學でい ５反射率曲線の測定と異つた點は光源と 視點の方位を條件として考慮に大れなけ ればならないと言うことである。

alkali blue (CI 705), そ bronze orange

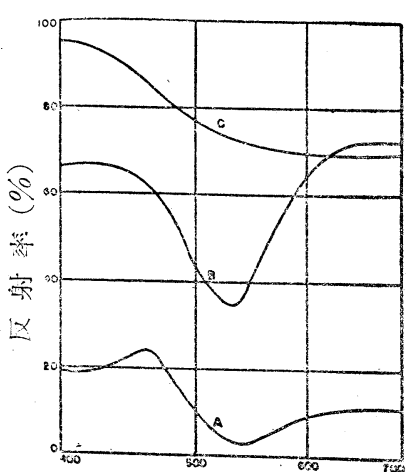

波长 $(\mathrm{m} \mu)$

- Fig. A Alkali blue Ink.

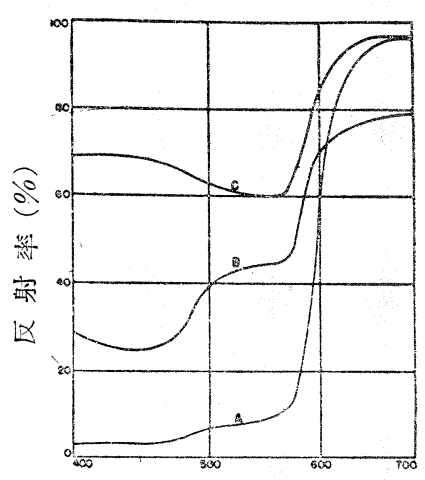

波長 ( $\mathrm{m} \mu$ )

Fig. B Bronze Ink. 
場合で, alkali blue では青色を bronze orange では 赤味を帶びた橙色を表わしている.

曲線 B はFig. A に拈いては入射角 $60^{\circ}$, 視角 $60^{\circ}$, 万位角 $180^{\circ}$ の偏光による反射曲線であり Fig. B で は光源看 $60^{\circ}$ 視角 $60^{\circ}$ 力位角 $180^{\circ}$ の垂直偏光によ る曲線である。Fig.に明らかなように alkali blue で は青 $(400 \mathrm{~m} \mu)$ と赤 $(100 \mathrm{~m} \mu)$ に大きな反射能があ らふれインクは紫であることを示す, bronze では带 色を帶びた橙色を表わしている出線 C は B z同じ條 件で, ブロンズを減少させるためにグリースの薄膜を 試料の表面に塗つて測定したもので, alkali blueでは らすい青色を bronze orange ではうすい橙色を示し ブロンズの特性は共に洞失している。

Frensnel (5) によれば異つた媒質の境界面に光が入 射した場会の反射エネルギーのマラクジョンは良く知 られているょうに

$$
\begin{aligned}
R & =\frac{1}{2}\left(\begin{array}{ll}
\sqrt{k^{\prime}} & \cos \phi-\sqrt{k} \cos \theta \\
\sqrt{k^{\prime}} & \cos \phi+\sqrt{k} \cos \theta
\end{array}\right)^{2} \\
& +\frac{1}{2}\left(\begin{array}{ll}
\sqrt{k} & \cos \phi-\sqrt{k^{\prime}} \cos \theta \\
\sqrt{k} & \cos \phi+\sqrt{k^{\prime}} \cos \theta
\end{array}\right)
\end{aligned}
$$

となる.ここで $\phi$ は大射角 $\theta$ は反射角で， $k^{\prime}$ として インクの䐷性常數 $k$ として空氣の䐷性常數を用いれ ば Fresnel 式なブロンズ現象に適用されることにな る Maxwell (5) の電傢論から考元て彈性常數は此誘 盙容量㯰き換えることが出來るから， $k, k^{\prime}$ は夫ふ 反射指雚吸光係數，と次の關係にあることがわかる。

$$
k=(n-i k)^{2} \quad(2 \mathrm{~A}) \quad k^{\prime}=\left(n^{\prime}-i k\right)^{2} \quad(2 \mathrm{~B})
$$

ここで $n, n^{\prime}$ は宾氣とインク皮膜の反射指數, $k, k^{\prime}$ 。 は夫々の吸光係數を示す.此の式を(1) 式に代入して $i$ て除すことによつてブロンズを訣算するための式が 得与れる。

又 Helmholtz（5）の分散理論によると反射指數と 吸光係數は頝料分子中の發色團の特性から試算するこ とが出來る。

毁与

$$
\begin{aligned}
n^{2}-k^{2} & =1+\frac{M \lambda^{2}\left(\lambda^{2}-\lambda^{2}{ }_{0}\right)}{\left(\lambda^{2}-\lambda^{2}{ }_{0}\right)^{2}+G^{2} \lambda^{2}} \\
2 n k & =\frac{M G \lambda^{3}}{\left(\lambda^{2}-\lambda^{2}{ }_{0}\right)^{2}+G^{2} \lambda^{2}} \\
M & =\frac{N e^{2} \lambda^{2}}{m \pi C^{2}} \\
G & =\frac{r \lambda_{0}{ }_{0}}{2 \pi m C}
\end{aligned}
$$

入は䛅算しょらとしている波長， $\lambda_{0}$ は吸收極大の波 長, $N$ は單位容積中の發色團の數, $e$ 沈發色團中の荷
電， $m$ は發色團中の質量，rは發色團に含なれる制 動怟抗。

これらの侙 の或る特性と單位容積中の數に低存していることが理 解される。これらの式を用いて實際に“interface bronze”を符算しようとする場合. 若し顏料粒子の 大きさが光の波長より大きい場会, 個々の粒子は異つ た光學特性をるつた展色劑中にある獨立した反射領域 と見做されるし，精子の大きさが光の波長に此べて小 さい場合は皮膜は均啠な畺の溶液の上うに見做すこと が出來る.（1)（2）式を用いる際. インクの吸光係數 と区射指數を波長の函數として決定することが必要で ある（空氣については既に知られている）吸光係數は インクを溶媒に可溶な狀態にして（例えば alkali blue の場会スルフォン化してェタノール水に溶解させる) 透過率曲線を測定することによつて求められる。(3) 式を使用に假利なように單純化すると

$$
n^{2}-\frac{2 n k\left(\lambda^{2}-\lambda^{2}\right)}{G \lambda}-\left(k^{2}+1\right)=0
$$

吸光係數の值からこの吸收帶の反射指數に及㳖す影

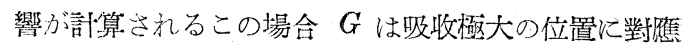
するように潠ぶ

“interference bronze”を計算する場合, 同じ振 動數をもつた波動が、位相と振幅を異にしたをきに生 じる重壘作用を與学る式が適用されると考えられる。 郎々

$$
R=A_{1}^{2}+A_{2}^{2}+2 A_{1} A_{2} \cos \Delta
$$

ここで $R$ は区射光の强度, $A_{1} A_{2}$ は夫々の波動の振 幅 $\Delta$ 世各波動の位相差.

溥い膜面に扮ける反射波動の振幅は (1) 式と少し異 つた形の Fresnel 式から試算される，第一面からの 反射光波の振湢 $A_{1}$ は

$$
A_{1}=\frac{v^{\prime} k \cos \phi-\sqrt{k^{\prime}} \cos \theta}{\sqrt{k \cos \phi+\sqrt{k^{\prime}} \cos \theta}}
$$

第二面的らの反射光波の振幅 $A_{2}$ は第一面からの䅗 過光のフラクション姿乘ずることによつて同樣に

$$
\begin{aligned}
A_{2}= & \left(\frac{2 \sqrt{k} \cos \phi}{\sqrt{k} \cos \phi+\sqrt{k^{\prime} \cos \theta}}\right) \\
& \times\left(\frac{\sqrt{k^{\prime \prime} \cos \theta-\sqrt{k^{\prime}} \cos \phi}}{\sqrt{k^{\prime \prime} \cos \theta+\sqrt{k^{\prime}} \cos \phi}}\right)
\end{aligned}
$$

$k^{\prime \prime}$ は第二つ媒質の彈性常數 $\psi$ は反射の第二次角迮 れの角 $\Delta$ は膜面の性質に低存し，头のよ弓に表現さ れる。

$$
\Delta=\frac{4 n d \pi}{\lambda} \cos \theta-\alpha
$$


$d$ は二つの並行な面の距離, $n$ は媒質の反射指數.

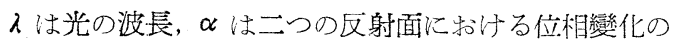
“interference bronze” 差を竐算する場合 $k, k^{\prime}, k^{\prime \prime}$, $\phi$ を知ることが必要でせる $\theta$ 攻び $\phi$ は次の式から計算 さ机る。

$$
\begin{aligned}
& \sqrt{k} \sin \phi=V^{\prime} / k^{\prime} \sin \theta \\
& v^{\prime} \overline{s i n} \theta=V^{\prime} / \bar{k}^{\prime} \sin \psi
\end{aligned}
$$

若し展色劑の皮膜が空氣中にある場合を假定すると

$$
k=1, \quad k^{\prime}=1.5, \quad k^{\prime \prime}=1, \quad \alpha=\pi
$$

$d=2.5 \times 10^{-5} \mathrm{~cm}$ に取机ば（5)〜(9) 式によつて

“interference bronze”夲計算することが出來る.

今 “ interface bronz"” そ “ interference bronze ”

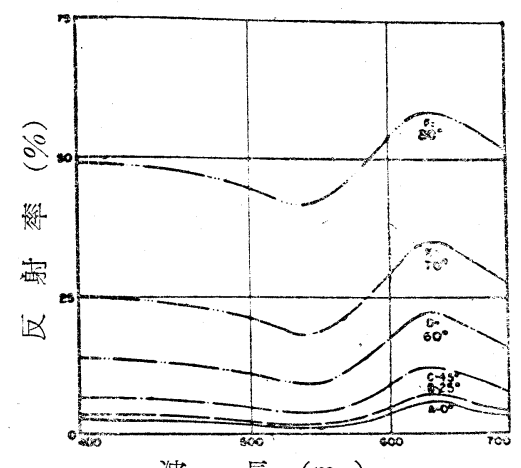

波長 $(\mathrm{m} \mu)$

Fig. C Alkali blue $\odot$ bronze の計算曲線

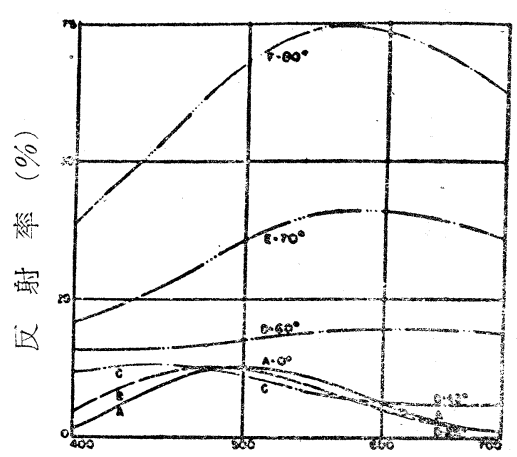

波長 $(\mathrm{m} \mu)$

Fig. D 展色劑は膜の bronze の 計算曲線

の差異を考察するために Fig. C Fig. D に夫々の反 射率曲線を種々な危度によつて計算した絓果を圖示す る.

これによると“interface bronze”では入射角を 異にした場合反射光の總䌡は異つているが，主波長 は同じ個處に保たれている (Fig.C)こ机に對して “ interference bronze”では大射角を變化させて計 算した結果は，廣い範圍の主波長の變化を與えている これが兩型の “bronze”を區別する實際的な方法で

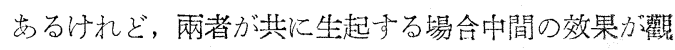
測されてくる.

\section{印刷个ンキ用顏料}

W. F. Spengeman (E. I. du. Pont de Nemours \& Co).

American Ink. Maker. July 1950. p. 35-37 55.

大日精化工業株式會社 長 谷 倫 夫

印刷インキ工業に使用せられている色の數は數百に 上るので今ここに顏料の化學と用途を詳細に述べる事 は不可能である，從つて印刷インキに用いら机る顏料 の簡單な分類を示しこの重要な型の化學と性質】价の 2.3 新しい餘り廣く知られてない用途に就いて概略的 に述べる.

顏料の分類は表に示す樣に無機と有機の 2 つ型に 大きく分けられる．更にこれは他の化學的性質により 細分する。

\section{印刷インキ用合成顏料の分類}

\section{I. 無機化合物}

A. クロム酸化合物

1. Medium Yellow 2. Light Yellow

3. Primrose and Lemon Yellows

4. Chrom Oranges 5. Molybdate Oranges

B. フエロシヤン化会物

1. Iron Blues.

II. 有機化合物

A. アゾータイプ

1. Pigment Dyes

(a) Toluidine Red, Para Reds, etc.

(b) Alkali Resistant Reds 